\title{
Sexting and Sexual Injustices against Women in Ghana: A Case of Biblical Narratives of Dinah And Tamar
}

\author{
Emmanuel Twumasi-Ankrah (D) 1 \& Joseph Gyanvi-Blay (D) 1 \\ 1 Department of Theology, Christian Service University College, Kumasi-Ghana.
}

\begin{abstract}
This paper evaluates the place of justice in sexual interactions between males and females in Ghana in particular and in Africa in general. It discusses the unfairness inherent in cases of rape, adultery and divorce and sexting in Ghana in light of African Biblical Hermeneutics. The study has discovered that issues of sexual injustices date back to ancient times with sexting being its latest dimension, especially in Ghana. Sexual injustices in any form have both cultural as well as religious connotations. Employing Narrative Criticism on the sexual stories of Dinah and Tamar in Genesis 34 and 2 Samuel 13 respectively, the study has established that the culture from which the Christian scripture originated was chauvinistic. Undoubtedly, one of the most integral causes is inherent in interpretation. The authors have therefore advocated for a reconstruction of those texts and worldviews by incorporating hermeneutics of inclusiveness and equality before God, using Jesus as the standard.
\end{abstract}

Keywords: Sexting, Sexual injustices, Biblical Hermeneutics, Biblical Narratives, Ethical.

Correspondence

Emmanuel Twumasi-Ankrah Email: etankrah@csuc.edu.gh

Publication History

Received 1st February 2021,

Accepted 23rd March 2021,

Published online 26th March 2021.

(C) 2021 The Author(s). Published and Maintained by Noyam Publishers.

This is an open access article under the CCBY license (http://creativecommons.org/licenses/by/4.0/).

\section{INTRODUCTION}

Biblical Hermeneutics is simply, an exegesis and interpretation of a biblical text. African Biblical Hermeneutics is relatively a very new enterprise only dating back to the 1960s when the Consultation of African Theologians' Conference was held in Ibadan to discuss the way forward for creating an exclusive African Christianity. ${ }^{1}$ So far, some of the issues that African Biblical Hermeneutics has attempted to address are oppression, liberation, feminism, missions, neotraditionalism, politics, and so on. This paper, however, attempts at developing a hermeneutic to reconstruct the African ideas on the issue of sex and its attending injustices. It touches on unfairness inherent in the cases of sexting, rape, adultery and divorce in Africa in general and Ghana in particular. The article primarily assesses the nature and place of justice in sexual intercourse between males and females in Africa. The paper traces the issue of sexual injustices from the Old Testament canon, relating cases cited in selected texts to that of $21{ }^{\text {st }}$ Century African society.

\section{METHODOLOGY}

The study employs a qualitative method. It uses a phenomenological approach in analysing the cases of sexting and sexual injustices in African society as reported by the print and electronic media. Through Biblical Hermeneutics, the selected biblical texts are examined and findings presented to indicate the historicity and ubiquity of the sexual injustices phenomenon. The biblical hermeneutics used here is Narrative Criticism. This approach has been chosen because one finds cases of all kinds of sexual abuses in the biblical narratives. The only kind that cannot be traced in the Bible may be sexting which appears to be a recent and new dimension of sexual injustices in the human society.

For the purposes of bringing out issues of sexual injustices in the Old Testament (OT), the case of biblical narratives of Dinah and Tamar have been chosen. In order to get the right meaning, the reading is brought out through Narrative Criticism. According to Mensah, Narrative Criticism approaches the Bible as a whole unit and as such, the meaning is found through the analysis of major features or elements of a biblical story such as the time and place of the

N. Onwu, "The Current State of Biblical Studies in Africa," The Journal of Religious Thought, 42, No. 2, (1984), 5. 
historical events and an emphasis on the role, time and place play in the story. In this case, interpretation emphasizes the passage itself. ${ }^{2}$ In this study, the concept of sexual injustices is derived solely from the stories of Dinah (Gen. 34) and Tamar (2 Sam. 13).

\section{Ethical and Biblical Perspectives on Sexual Injustices}

The Bible has been the most influential document in shaping the ideas of Western culture regarding the place of women and the relationship between the sexes. ${ }^{3}$ Studies have shown that in Africa, the Bible has become such a formidable force, playing an integral part in the religious and socio-economic development of the continent. ${ }^{4}$ In light of this one may wonder if the Bible has affected and seeks to shape the psyche and worldview of African readers concerning sexual injustices.

Reading the Bible, one comes across the incidence of sexual abuse as well as laws and codes regulating the sexual behaviour of the people. This implies that the issue of sexual injustices dates back to ancient times. Studies on the subject of rape revealed that rape has long been part of human experience, confirmed by the numerous rape stories and passages in the Bible. It showed that rape occurs in epidemic proportions worldwide and that it is a reality in times of peace as well as war. ${ }^{5}$ The focus of the study here is to analyse some of these incidences of sexual abuse and the legislations against sexual injustices from the viewpoint of the Bible and tie it in with the African worldview. Based on the analysis, an attempt is made at developing a framework that could address this social canker.

The Bible is replete with cases of sexual injustices. In 2 Samuel 13:1ff, Amnon one of David's sons rapes Tamar, his half-sister. The setting of the story reveals clearly an androcentric society where the male gets whatever he wants and asks for at all cost. Every character in the story including Tamar herself is seen doing the bidding of Amnon, the male, in order to help him achieve or get what he wants. For instance, Jonadab comes in to remind him of his position as the son (male) of the king who had Tamar as one of his properties (vv. 3-5). King David cannot be exonerated from this either. He gives in to the selfish demands of his son, even though he knows the implications of Amnon's request of Tamar, which was; coming to cook in his sight so that he could eat from her hand (v. 6). Amnon's words and actions prior to the act itself were too erotic to elude Tamar (vv. 9-10) but she could not flee nor ask questions because of the worldview of the supremacy of the male in that society. Also, partnering with Amnon in the crime are the people in his house at the time Tamar gets there. They readily agreed to leave the house as soon as they were ordered to do so to make it easier for Amnon to pounce on the lady to satisfy his ego as a male (v.9). It appears from a critical reading that everybody was aware of what Amnon was up to but took no steps to prevent him because it was probably normal for the male to exhibit his dominance and authority over the female.

A similar abuse was perpetrated against Dinah, the daughter of Jacob by Shechem. The writer of the book of Genesis narrates that Dinah visited her women friends of Shechem. When Shechem, son of Hamor the king saw her, he raped her (Gen. 34:1ff). However, unlike Amnon's case, Shechem, after that illegal sexual act, requested to marry Dinah. Interpreters commenting on Genesis 34 choose to belittle the rape by offering various arguments and interpretations that either obfuscate, deny or avoid the rape, or they turn to the age-old method of blaming the victim. ${ }^{6}$

\section{Interpretations of the Biblical Narratives}

The rape of Dinah is a classic case of acquaintance; or date rape. Victims of acquaintance rape tend to remain silent about their experiences because this kind of rape is not recognised as a sexually violent act. In fact, date rape is not perceived as rape since the rapist and victim knew each other and petting prior to the rape may have instigated the rape. The woman is frequently blamed for her lack of resistance, so she remains silent for fear of being disbelieved. ${ }^{7}$ Dinah's silence has allowed interpreters to imagine that she consented. Date rapists often appear "normal" after the incident and pretend that nothing bad happened. They know that they have taken advantage of a woman and might attempt to contact her again, pretending to be friends. Shechem fits this description, although the outcome of the story is complicated by his murder by Dinah's brothers ${ }^{8}$ and taking as part of the booty, the innocent women of the city of Shechem. There is a likelihood that the brothers of Dinah, likewise abused sexually in retaliation, the women they captured from the city of Shechem. Yet, this part of the story is silent in the narrative. The focus is on Dinah who is portrayed as a reckless and roaming girl only vulnerable to sexual abuse. Genesis 34 is a disturbing story about sexual violence which makes it

\footnotetext{
Augustine M. Mensah, The Hebrew Bible and the five books of Moses,(Cape-Coast: Nyakod Printing Press 2016$), 47$.

Susanne Scholz, "Was it really rape in Genesis 34?" in Escaping Eden: New Feminist Perspectives on the Bible (ed. Harold C. Washington, S. Lochrie Graham and Pamela Thimmes, New York: New York University Press, 1999), 182.

4 Keith Augustus Burton, “The Blessing of Africa: the Bible and African Christianity”, The Journal of African American History Vol. 94 , No. 1 (Chicago: University of Chicago Press, Winter, 2009), 89.

For the work done by feminists on rape, see Susanne Scholz, "Through Whose Eyes? A 'Right' Reading of Genesis 34" in Genesis: A Feminist Companion to the Bible (ed. A. Brenner, Sheffield: Sheffield Academic Press, 1998), 161-164.

Frances Klopper, "Rape and the Case of Dinah: Ethical Responsibilities for Reading Genesis 34", OTE, 23/3, (2010), 653.

Susanne Scholz, Sacred Witness, Rape in the Hebrew Bible, (Minneapolis: Fortress Press, 2010), 30.

Scholz, Sacred Witness, 38.
} 
particularly suitable for identifying readers' views on rape. In most legal systems, what happened to Dinah would have been considered rape. Nonetheless, in their treatment of the story, interpreters sidestep or belittle the rape incident. ${ }^{9}$ Providing a reason for this belittling of the plight of Dinah in the Genesis 34 narrative, Parry argues that Dinah's rape is marginalised and she is silenced because in ancient Israel, rape was not a crime against women, but against men (husbands and fathers). Female sexuality was considered male property. ${ }^{10}$

The crucial question is how are these texts read? What is the interpretation given by readers? It is important to note that many interpreters carefully select these texts when they want to alert young women about their responsibility to remain chaste. As a result, the emphasis is always on the negligence of Dinah and the timidity of Tamar. The texts are primarily used to press home the fact that females are at risk of sexual abuse any time by males and it is their sole responsibility to disallow its occurrence. This is confirmed by Schroeder that "through the centuries commentaries minimised the rape by blaming Dinah for "going out" to meet the Shechemite daughters as recorded in verse 1, although contemporary critical commentators rarely openly revert to this method. In public opinion, however, excuses for rape still flourish and thrive: "She was asking for it," "She enjoyed it," "Boys will be boys."11 In the $19^{\text {th }}$ century, for instance, literature concerning how even women approached stories of sexual injustices against women in the Bible could only be described as laidback. Those who dared to comment on Genesis 34, used Dinah's behaviour in moral lessons as an example for young girls of how not to behave like her. By avoiding these difficult stories, they tried to live up to an ideal of protected and refined ladies. ${ }^{12}$

\section{Interpretations of the Narratives from Scholars in the Medieval Period}

Scholars in the medieval period and Reformation era interpreted biblical texts by reading their cultural perceptions and assumptions into the texts. ${ }^{13}$ Augustine (345-430 C.E.) regarded rape as God-sent, for it teaches women to think again about future sinning. ${ }^{14}$ To many of these commentators, Dinah's sin was not so much of her going out to see the girls in the vicinity; her great vice was that she "went awalking to gaze and see fashions as women were ever desirous of novelties and given to needless curiosity." ${ }^{15}$ Curiosity caused women to compare their own beauty with the appearance of others, resulting in the sins of seduction, pride and vainglory. ${ }^{16}$ Many readers attributed the sin of lust to Dinah, of enjoying the sensual delights of the rapist's attention. ${ }^{17}$ Martin Luther (1483-1546), by reading Genesis 34 historically from the perspective of a father with daughters, had more sympathy for Dinah and cast less blame on her than some other reformers like Calvin and Zwingli. He knew that daughters are curious and cautioned the parents to warn them against venturing out alone. ${ }^{18}$

This study proposes a holistic approach to some of these Biblical texts that speak on justice and violation of human dignity rather than the hermeneutics of oppression, fear and segregation. Instead of focusing on the female and putting in her the fear of males, African biblical hermeneutics must also address the male, bringing out clearly his responsibility to control his sexual drive and respect the dignity of the female.

Employing the biblical texts (stories of Amnon and Shechem), there is the need to highlight the weaknesses and flaws of these characters over against that of the men in Africa. The consequence of their actions is a major theme interpreters need to explore hermeneutically. One can see from the stories that indeed, "the wages of sin is death" (Rom. 6:23). Amnon was killed by Absalom to avenge the ordeal of his full blood sister, Tamar (2 Sam. 13:28-29). For Shechem, he and all the men in the city were gruesomely murdered by the brothers of Dinah (Gen. 34:25-29). The notion that some people are naturally more prone to evil than others due to their genetic make-up is neither here nor there. It is a fallacy that needs not to be given attention. Every human is responsible for his/her actions and inactions. Men have no right to pounce on any female within their reach. Assuming without admitting that Dinah was roaming about -did that give Shechem any right, be it legal or moral to abuse her sexually? Tamar on the other hand was not out there but quietly minding her business at home until she obeyed her father's instructions to go and nurse her half-brother on his sick-bed. How could her hospitable acts towards her blood brother be interpreted to be her readiness for sexual abuse?

\footnotetext{
Joy Schroeder, Dinah's Lament. The Biblical Legacy of Sexual Violence in Christian Interpretation (Minneapolis: Fortress Press, 2007$), 3$, 11.

Robin Parry, Old Testament Story and Christian Ethics: The Rape of Dinah as a Case Study, (Milton Keynes UK: Paternoster, 2004$), 234-237$.

Schroeder, Dinah's Lament, 238.

12 Marion Taylor \& Heather Weir, Let her speak for herself: Nineteenth century women writing on women of Genesis, (Waco, Texas: Baylor University Press, 2006). 440.

13 Klopper, "Rape and the Case of Dinah", 659.

14 Scholz, Sacred Witness, 9. See also Schroeder, Dinah's Lament, 66.

5 Gervane Babington (1550-1610), Bishop of Llandaff, Wales, quoted by Shroeder, Dinah 's Lament, 49.

6 Schroeder, Dinah's Lament, 17.

Schroeder, Dinah's Lament, 11.

For a discussion on Luther's empathetic interpretation of the Dinah story in his Genesis commentary, see Schroeder, Dinah's Lament, 33-40.
} 


\section{Cases of Rape in Ghana}

The cases of rape recorded in the Bible do not make the issue a religious one but they rather show how pervasive and historical the issue of sexual injustices is. In Africa, cases of rape are ever-increasing phenomena, mostly orchestrated by men against women. Ghana is not an exception. According to section 98 of Act 29, rape is defined as having carnal knowledge of a female of not less than sixteen years without her consent. This implies that as long as a person is sixteen years or above, one can have sexual intercourse with her by her express or implied consent. With the advent of the Criminal Code Amendment (Act 554), the offence of rape is now a first-degree felony carrying a sentence of not less than five years and not more than twenty-five years (Section 97). ${ }^{19}$

In Ghana, the offence of rape is gender-specific. Thus, a man cannot be raped, not even by his fellow man. In situations like these, it is considered unnatural carnal knowledge and it carries the same sentence as rape. Most importantly, in Ghana, a woman cannot be the perpetrator of rape. Under no circumstances will it be held that a woman has raped a man. ${ }^{20}$ However, one cannot deny the fact that a male too can be raped either by another male or by a female. This is in sync with Scholz's definition of rape as "the crime of forcing another person to submit to sex acts, especially intercourse."21

Even though the punishment for rape as prescribed by the Law seems quite severe, reported cases of rape keep on increasing in the country. In 2014 alone, the Domestic Violence and Victims Support Unit (DOVVSU) of the Ghana Police Service reported that they recorded about Three Hundred and Thirty-Five (335) cases of rape and One Thousand, Two Hundred and Ninety-Six $(1,296)$ cases of defilement. ${ }^{22}$ The perpetrators were of varied social strata ranging from prophets, politicians, celebrities, teachers, close relatives, schoolmates to strangers (especially, robbers). Data gathered from 2011-2016 by DOVVSU shows that more females continued to suffer from rape and assault with only a handful of the victims being males. Out of 1,862 reported cases of rape, there were only 6 males. ${ }^{23}$

In 2015, when the ace broadcaster, Kwesi Kyei Dakwa, was alleged to have raped a 19-year old lady, Ewureffe Orleans Thompson during a show at the African Regent Hotel, at least, four more women were reported to have made similar claims that 'the gentleman' had done a similar thing to them on different occasions. ${ }^{24}$ Similarly, Asamoah Gyan, the erstwhile Ghana National Team striker was allegedly accused of raping a lady who was a student from the University of Ghana. ${ }^{25}$ In 2006, it was reported that a young lady was gang-raped in Accra on the eve of her birthday by five young men, one of whom was her classmate. ${ }^{26}$ This brings to fore the alarming rate of rape cases in Ghana. It must be stated that these reports constitute only reported cases. Given the nature of the Ghanaian culture, the unreported cases are likely to be about twice or thrice higher than the reported ones.

One cannot agree more with Elizabeth Ohene, a BBC columnist and a former Ghana government minister, herself, a two-time victim of sexual abuse that this situation of rape will persist unless Ghanaians are ready to talk about these matters. ${ }^{27}$ The crucial question is, what is the nature and place of justice in cases of rape? Could rape be a mutually consented sexual act? Who is to blame in cases of rape; the man or the woman? In Africa, on daily basis, most victims of rape are denied justice. Many a time, the story is not told at all. Apart from the threats the male perpetrators normally give to their victims, the culture and the social milieu of the victims screw them up. By silencing the victim and not taking a stance against the rapist, the rampant rape epidemic in current times is perpetuated..$^{28}$ The persistence of rape makes silence about the "unmentionable sin" of rape dangerous and complicit since silence enables the violent status quo and keeps it alive. It leads to victims blaming themselves and living with guilt for the rest of their lives. ${ }^{29}$ Women, in the eyes of many Africans, are better only in sexual activities. Hence, a sexual crime against a woman is probably not a big deal.

Another misconception from the board room of the chauvinists is that sexual acts between a woman and a man cannot be done unless the two have mutually consented and benefitted. This flaws the case of the few women victims who attempt to seek justice in either the judicial court or traditional court after being sexually abused. A typical example

19 Michael Sumaila Nlasia, "Inadequacies of the Definitions of Sexual Offences in the Criminal Offences Act", Ghana Law Hub, April, 29, 2019, accessed

December 15, 2020. https://ghanalawhub.com/inadequacies-of-the-definitions-of-sexual-offences-in-the-criminal-offences-act/

20 Nlasia, "Inadequacies of the Definitions of Sexual Offences in the Criminal Offences Act".

21 Scholz, Sacred Witness, 129.

22 Ebenezer Owusu-Addo, Sally Owusu-Addo, Ernestina Antoh, "Ghanaian media coverage of violence against women and girls: implications for health promotion." BMC Women's Health 18, No.129 (2018). https://doi.org/10.1186/s12905-018-0621-1.

23 Nlasia, "Inadequacies of the Definitions of Sexual Offences in the Criminal Offences Act".

24 Marian Efe Ansah and Edwin Kwakofi, “KKD’s Alleged Rape Victim Withdraws Case,” Citifmonline, January 13, 2015 , accessed January $26,2021$. https://citifmonline.com/2015/01/kkds-alleged-rape-victim-withdraws-case/

25 Comfort Asante, "New Attorney General to Continue Asamoah Gyan’s Rape/Sodomy/Extortion Case Come Wednesday 26th April, 2017," Ghana Celebrities, September 7, 2017, accessed December 26, 2020,

https://www.ghanacelebrities.com/2017/04/24/new-attorney-general-continue-asamoah-gyans-rapesodomyextortion-case-come-wednesday-26th-april-2017/

26 Daily Guide Network, “4 Teenagers rape girl, 19”, GhanaWeb, May 30, 2015, accessed February 25, 2021. https://www.ghanaweb.com/GhanaHomePage/NewsArchive/4-Teenagers-rape-girl-19-346215.

27 Elizabeth Ohene, "Why I Went Public after Being Raped, 67 Years Later," BBC News, October 12, 2019, accessed December 15, 2020. https://www.bbc.com/news/world-africa-50014745

28 Klopper, "Rape and the Case of Dinah", 652.

29 Klopper, "Rape and the Case of Dinah", 659. 
occurred during the trial of Kwesi Kyei Dakwa on allegedly raping a 19-year old lady, he denied the accusation and submitted that they had consensual sex in the washroom of the hotel. ${ }^{30}$ In a situation like that the victims are enjoined to prove beyond a reasonable doubt that they never consented to the act. This becomes an arduous task almost impossible for the women. As a result, the accused normally go unpunished since many of the victims abandon the case. Sometimes, society itself takes turns to blame the victims by questioning, "Why did she go there?" "What was she doing there?" Why did she not scream?" and so on and so forth.

Indeed, in androcentric societies such as Africa, rape is an expression of supremacy. That is why it is popular to hear, "All women want to be raped", "She was asking for it; she changed her mind afterwards and cried, rape!" "The women shouldn't wear provocative dresses" etc. This is consistent with Brownmiller's assertion that rape has nothing to do with "sexual gratification" or satisfaction of "natural urges". It is more of a criminal and violent act against minorities and less privileged of society than a sexual relationship. Sexual violence is simply the imposition of domination and authority, the humiliation, sometimes annihilation of someone who cannot retaliate. ${ }^{31}$ This probably accounts for the recent act of (sexting) taking and sharing of videos of sexual acts with females on the internet with impunity in Africa.

\section{Adultery and Divorce}

The Advanced English Dictionary defines 'adultery' as extramarital sex that willfully and maliciously interferes with marriage relations. ${ }^{32}$ This definition does not suffice in the African worldview. The demand for fidelity is laid at the doorstep of the wives but to many husbands, it is not applicable. In the Ghanaian socio-cultural worldview, if a husband engages in extramarital affairs, it is no news. In fact, he can take as many concubines as he so wishes. The worst that he could face from his wife is for her to demand a sort of compensation if he attempts to officially marry an additional wife. However, if a wife is accused of engaging in any form of sexual activity with another man even once, her judgement is prejudicial, divorce, amidst assaults, humiliation and banishment from her matrimonial home. But for the PNDC Law 111 (Interstate Law of succession), many of the accused sexually infidel wives were in the past, driven out of their matrimonial homes without any property to support themselves and the children.

So, in Africa, it is comparatively rare for wives to seek divorce on the basis of adultery because adultery is defined, detected and determined by men. This is in keeping with Brownmiller's speculations that once a male takes a title to a specific female body, he assumes the burden of fighting off all other potential attackers or scaring them off $^{33}$ his property (woman). But the price some women pay for their protection is heavy -they become estranged from other women and acquaintances. Some of them are even forced by their men to quit their occupations for fear of being sexually harassed or abused by their male co-workers and bosses.

\section{Sexting: A New Dimension of Sexual Injustices in Ghana}

Sexting is the practice of sending and receiving explicit sexual images via mobile phones. ${ }^{34}$ This dimension of sexual abuse is relatively new and more sophisticated. The recent crave for this activity and the worrying news of 'leaked sex tapes' on social media has grown exponentially in Ghana due to the accessibility of technology. This is confirmed by Adu-Kumi who studied the involvement of college students in sexting practices in Ghana. He decries, "circulating sexually explicit materials on social media platforms has in recent times become a spectacle, especially, among college students in Ghana". ${ }^{35}$ In 2015, media reports indicated that a young photographer, somewhere in the Eastern Region of Ghana who had been luring several women to bed ended up filming the various sexual acts with his female victims. Sadly, these videos were later seen streaming life on the internet, causing panic and horror in that part of the country. ${ }^{36}$

A similar incident was reported in early 2016 of a leaked sex video allegedly involving a lady from one of the prestigious universities in Kumasi. That two-minute sex video which went viral on social media showed the face of only the female but not the male sex partner. It was even alleged that the said video was shown live on the campus of the said university by some students. However, the allegations of the public streaming and the lady being a student of that university have been denied by the authorities of the university. ${ }^{37}$ Also, in Sunyani, a sex video, allegedly involving a female police officer was leaked and shared on social media. ${ }^{38}$ In fact, sexting is on the rise especially, among the youth

\footnotetext{
30 Ansah and Kwakofi, "KKD’s Alleged Rape Victim Withdraws Case".

31 Susan Brownmiller, Against Our Will-Man, Women and Rape, (Penguin Books: USA), 1976, 71.

32 Albert Sydney Hornby, Michael Ashby and Sally Wehmeier, Advanced Learners' English Dictionary (7 ${ }^{\text {th }}$ ed.), (Oxford: Oxford University Press, 2005).

3 Brownmiller, Against Our Will, 72.

34 Karen Peterson-lyer, "Sexting”, Society of Christian Ethics, Vol. 33, No. 2, (Fall/Winter, 2013), 93-110.

35 Benjamin Adu-Kumi, "Sexuality Going Viral: Using Whatsapp as a Site for Sexual Exploration among College Students in Ghana", An Unpublished Master of Arts Thesis Submitted to the School of Journalism and Communication of the University of Oregon, (June, 2016$), 11$.

36 S. Quarshie, "Church Elder Involved in Sex Tape Saga”, January 29, 2015, accessed, March 22, 2021. https://www.pulse.com.gh/filla/shocking-church-elder-involved-in-sex-tape-saga/ldhqjqb

37 Egbert Faibille, “KNUST Sex Tape: Female Student's Right Violated”, May 4, 2016, accessed March 22, 2021 https://www.myjoyonline.com/knust-sex-tape-leak-female-students-right-

38 Reports made on Nhyira 104.5FM, "Police Woman in Sex Video", May 18, 2016, accessed March $22,2021$. https://de-de.facebook.com/nhyira104.5fm/posts/police-woman-in-sex-video-a-sex-video-of-a-woman-believed-to-be-a-police-personn/1073617989348637/
} 
in Ghana. The study has observed that there are far more female victims than males. This is not just a new phenomenon but a dimension that poses a new challenge in the arena of law and justice, rights and privileges, citizens' responsibilities and privacy.

Peterson-lyer examined this practice among teenagers in light of a Christian Feminist Approach to justice. She recommends:

Without harmfully exhorting girls' sexual "purity", we must nevertheless develop a moral framework that challenges the practice of sexting while simultaneously empowering young women to claim primary control over their own sexual experience. For Christians, justice addressed to sexting, must attend to sexual injustice even as it promotes genuine freedom, embodiment, mutuality and relational intimacy and equality. ${ }^{39}$

Indeed, sexting has become a moral problem in Africa with the accessibility of cellular technology to the extent that a framework or hermeneutics is necessary to address it. However, it is likely for hermeneutics to help deal with the problem in other parts of the world since the problem seems to be a global one. In the USA for example, it is reported that one in five teens ( $22 \%$ of teen girls and $18 \%$ of boys) have electronically sent or posted online, nude or semi-nude photos of themselves. ${ }^{40}$

It is important to note that sexting is normally practised between boyfriends and girlfriends. The boys are seen as offenders while the girls are seen as victims. This is because the boys normally love to show the photographs and the videos of their girlfriends to others for mere peer-fame usually without the consent of the girls. However, in many cases, the photos and the videos are shared by the men when a rift occurs between them and their sexual partners. That is why in most cases of leaked sex tapes, one sees the nude images of only the female victims but not the male partners. The men claim to do this in retaliation. Nevertheless, this is obviously a classic display of male dominance over the females -making them properties to be owned by men. This male tendency toward females is incurably dominant in Africa and it could be the inherent cause for the numerous cases of rape, defilement, adultery and divorce.

\section{Jesus' Teaching and Ministry towards Women, a Framework for Hermeneutics of Inclusiveness}

One hardly finds a change in position in Jesus' own comment on Moses' directive with regards to who could divorce and be divorced as seen in Matthew 19:3-12. Yet, in Mark's gospel especially, Jesus seems to differ from Moses by pointing out the possibility of a woman also wanting to divorce her husband (Mk. 10:10-12). However, Jesus' attitude toward women in general, especially those that suffered sexual injustices was far more favourable than both the leaders before him and those of his day. His encounter with the Samaritan woman who had had multiple sexual relations (Jn. 4:1ff) is remarkable. Jesus' intervention in the case of a woman alleged to have been caught in adultery was timely and splendid as a Jewish leader (Jn. 8:3-11). ${ }^{41}$ Women such as Mary Magdalene and Mary who were once known to be sexually sinful were very close to him throughout his ministry. It is therefore not out of place that many feminist theologians consider Jesus as a feminist and a liberator of the female.

Since Jesus Christ is considered to be greater than Abraham, Moses, David and all the prophets; his life and teachings have become the standard for all Christian theologies, all hermeneutical attempts must be done in light of what Christ teaches and stands for. The authors, therefore, advocate for the hermeneutics of inclusiveness and equality before God, using Jesus as the standard.

\section{CONCLUSION}

This paper has assessed the nature and place of justice in sexual intercourse between males and females in Africa. It has discussed the injustices inherent in cases of rape, adultery and divorce and sexting in Africa in light of African Biblical Hermeneutics. The study has discovered that issues of sexual injustices date back to prehistoric times with sexting being its newest dimension, especially in Ghana. The inclination of all forms of sexual injustices is more cultural than religious. Nonetheless, this study has shown that religion as part of the culture of people has also played a role in strengthening sexual injustices over the years. With this, the study has intimated that the culture from which the Christian scripture originated was male-oriented, giving room for the display of male dominance and oppression. However, the worst of the causes is inherent in hermeneutics. The study has therefore advocated for a re-reading of the texts through hermeneutics of inclusiveness and equality before God, using Jesus as a framework.

\footnotetext{
39 Peterson-lyer, “Sexting”, Society of Christian Ethic, 93-110.

40 Brandon Scott Marker, "Sexting as Moral Panic: An Exploratory Study into the Media's Construction of Sexting", (2011), Online Thesis and Dissertation, submitted to Eastern Kentucky University, Paper 12, 23.

${ }^{41}$ As unfair as the culture of the Jews in Jesus' day was, the leaders reported the sexual sin of the woman but left alone the man with whom she had intercourse. Jesus however, condemned not the woman.
} 


\section{ABOUT AUTHORS}

Emmanuel Twumasi-Ankrah is a lecturer in the Faculty of Humanities, Department of Theology at the Christian Service University College, Kumasi-Ghana and a PhD candidate at the Religious Studies Department of Kwame Nkrumah University of Science and Technology, Ghana, majoring in Old Testament and Biblical Hebrew.

Joseph Gyanvi-Blay is a lecturer in the Faculty of Humanities, Department of Theology at the Christian Service University College, Kumasi-Ghana. He holds both M. A and MPhil. In Religion and Human Values from the University of Cape Coast.jgblay@csuc.edu.gh

\section{BIBLIOGRAPHY}

Adu-Kumi, Benjamin. "Sexuality Going Viral: Using Whatsapp as a Site for Sexual Exploration among College Students in Ghana", An Unpublished Master of Arts Thesis Submitted to the School of Journalism and Communication of the University of Oregon, June, 2016.

Ansah, Efe Marian and Kwakofi, Edwin. "KKD's Alleged Rape Victim Withdraws Case", Citifmonline, January 13, 2015. Accessed January 26, 2021. https://citifmonline.com/2015/01/kkds-alleged-rape-victim-withdraws-case/

Asante, Comfort. "New Attorney General to Continue Asamoah Gyan's Rape/Sodomy/Extortion Case Come Wednesday 26th April, 2017", News Ghana, September, 7, 2017, Accessed December 26, 2020.

https://www.ghanacelebrities.com/2017/04/24/new-attorney-general-continue-asamoah-gyansrapesodomyextortion-case-come-wednesday-26th-april-2017/

Brownmiller, Susan. Against Our Will-Man, Women and Rape, Penguin Books: USA, 1976.

Burton, Augustus K. "The Blessing of Africa: the Bible and African Christianity", The Journal of African American History Vol. 94, No. 1 Chicago: University of Chicago Press, Winter, 2009.

Daily Guide Network “4 Teenagers Raped Girl, 19”, Ghanaweb, May 30, 2015. Accessed February 25, 2021. https:// www.ghanaweb.com/GhanaHomePage/NewsArchive/4-Teenagers-rape-girl-19-346215

Faibille, Egbert. "KNUST Sex Tape: Female Student’s Right Violated”, Myjoyonline., May 4, 2016. Accessed March 22, 2021, https://www.myjoyonline.com/knust-sex-tape-leak-female-students-right-.

Hornby, Sydney Albert, Ashby Michael and Wehmeier Sally. Advanced Learners' English Dictionary (7 $7^{\text {th }}$ ed.), Oxford: Oxford University Press, 2005.

Klopper, Frances. "Rape and the Case of Dinah: Ethical Responsibilities for Reading Genesis 34”, OTE, 23/3, 2010.

Marker, Brandon Scott. "Sexting as Moral Panic: An Exploratory Study into the Media's Construction of Sexting". Online Theses and Dissertations, Paper 12, 2011.

Mensah, M. Augustine. The Hebrew Bible and the five books of Moses, Cape-Coast: Nyakod Printing Press, 2016.

Ohene, Elizabeth. "Why I Went Public after Being Raped, 67 Years Later", Accessed, December 15, 2020 https://www.bbc.com/news/world-africa-50014745..

Onwu, N. "The Current State of Biblical Studies in Africa," The Journal of Religious Thought, 42/2, 1984.

Owusu-Addo, E., Owusu-Addo, S.B., Antoh, E.F. et al. Ghanaian media coverage of violence against women and girls: implications for health promotion. BMC Women's Health 18, 129 (2018).

https://doi.org/10.1186/s12905-018-0621-1

Parry, Robin A. Old Testament Story and Christian Ethics: The Rape of Dinah as a Case Study. Milton Keynes UK: Paternoster, 2004.

Peterson-lyer, Karen. "Sexting", Society of Christian Ethics, Vol. 33, No. 2, Fall/Winter, 2013.

Quarshie, S, “Church Elder Involved in Sex Tape Saga”, January 29, 2015. Accessed, March 22, 2021. https://www.pulse.com.gh/filla/shocking-church-elder-involved-in-sex-tape-saga/ldhqjqb

Scholz, Susanne. "Through Whose Eyes? A 'Right' Reading of Genesis 34." Pages 150-171 in Genesis: A Feminist Companion to the Bible. Edited by A. Brenner, Sheffield; Sheffield Academic Press, 1998. . Sacred Witness. Rape in the Hebrew Bible. Minneapolis: Fortress Press, 2010.

Schroeder, Joy A. Dinah's Lament: The Biblical Legacy of Sexual Violence in Christian Interpretation. Minneapolis: Fortress Press, 2007.

Sumaila Nlasia, Michael. "Inadequacies of the Definitions of Sexual Offences in the Criminal Offences Act", Ghana Law Hub, April, 29, 2019. Accessed December 15, 2020.

https://ghanalawhub.com/inadequacies-of-the-definitions-of-sexual-offences-in-the-criminal-offences-act/

Taylor, Marion A. \& Weir E. Heather. Let her Speak for Herself: Nineteenth Century Women Writing on Women of Genesis. Waco, Texas: Baylor University Press, 2006. 